\title{
New method to support decision making process in the local economic development of Hungary
}

\author{
Melinda Nagy-Molnár \\ Szent István University, \\ Hungary \\ E-mail: \\ melindamolnar@yahoo.com
}

Endre Lendray

Szent István University,

Hungary

E-mail:

lendvay.endre@responsum.hu
This study provides a method that supports local governments' efforts to develop their economy with a set of instruments built on evidence-based decision making. The authors' first objective is to define the action space and opportunities by examining the relation between environmental factors and internal resources. To achieve this, an analytical tool was designed that discovers - with an indicator system - the network of internal factors of a settlement economy and the external environment affecting it. When studying local economic development, it is important to assess the local economy in situ and its interaction with its surroundings.

The second objective is to discover and show the connection between the available tools and environmental factors, and thereby enable decision makers to take development actions based on evidence. The tools provide a quantified relationship between the possible actions and environmental factors made available by these actions. It is essential to determine which actions affect which environmental factors, and which factor they can help adjust. It is assumed that the development tools used by local governments are not equal in their effectiveness when interacting with the different environmental factors.

The authors' third objective is to discover the relationship between the tools and internal resources, thereby ensuring a base for planning resources necessary for implementing economic development actions. According to their preliminary assumption, the relations between the available resources and local governmental tools are not of the same strength; therefore, it justifies their analysis.

The next assumption is that areas affected by the same environmental factors can be devel- 
oped to different extents with local governmental tools. However, it is also assumed that a settlement can be developed according to a predefined target by a systematic application of appropriately selected tools; thus, every area can be developed. Economic factors are related to each other; they constitute a living fabric. The authors' objective is to discover the hidden relations in a local economy. According to their assumption, understanding these relations allows indirect influence of

Keywords: economic factors that are more difficult to local economic development, shape.

PESTEL-analysis, The authors' final objective is to provide strucscorecard, tured information for economic development benchmarking actions.

\section{Introduction}

The trump card of successful settlements: the successful development of local economy. To be successful, settlements should ensure a successful development of their economy. Our research develops a method for local municipalities that supports complex decision making which ensures that the action areas of the local economy are properly designated so that they can be influenced by the local government. First, it is worth clarifying some key concepts.

Local economic development is an emphatic question of the human-environment relations, which has been evaluated differently from time to time (Köszegi et al. 2015). The concept of local economic development is not unambiguous. According to G. Fekete (2005), local economic development is the conscious intervention in the ongoing changes in a region. According to some, it is a strategy, which effectively unites the local resources for creating workplaces (Capková 2005). A different approach states that the development of the local economy is a conscious intervention, where the initiator can be external or internal; however, the key figure of the process is a local character (Mezei 2006). According to Lengyel (2013), the development of the local economy is a conscious local community intervention in the economic process to ensure sustainable local development.

Although the development of a local economy is first and foremost an economic question, in reality, it depends on several economic, social, and environmental factors. Every factor that influences the local living conditions and quality of life, affects the development or success of a settlement (Ludescher 2010). Several studies prove that successful settlements have a stable economy and community. One stream of study states that social capital is one of the most important factors determining success (Bodor et al. 2017). Bartik (1995) and Čapkova (2005) state that

Regional Statistics, Vol. 8. No. 2. 2018: 69-91; DOI: 10.15196/RS080207 
besides emphasising the positive quality of life, sustainability is also important. On the other hand, a lack of info-communication tools leads to regional disparities (Páger-Zsibók 2014). It is also important to highlight that since settlements are characterised by different features, they have different methods available to them to achieve their goals.

According to Péteri (1994), although local governments do not have a significant effect on economic processes, they should intervene. Faragó (2004) concludes that since intervention opportunities are limited, they should be used only when the market is not functioning properly. Others say that settlements are capable participants in the economic development process; they are not just drifting with the tide. The key to this is adaptability. Amidst constantly changing conditions, settlements can be successful if they can adapt to their surroundings (Jedynak et al. 2015). Adaptability depends on a combination of natural factors and their effect on their settlements, internal resources, and the tool sets available to settlements. Local economic development requires the determination of tools that can be used for tasks and goals. The settlements, as municipalities, have tools with different characteristics, which can strengthen or weaken each other's effects due to their complex system roles. Some of the tools used by the settlements are unique (e.g. local taxes, local communities, etc.), while others (e.g. administrative and legal regulations) function alike anywhere in the country. The success of a settlement depends on its ability to find effective tools and use them.

The objective of our study is to show, through a domestic example and with the help of methods known and used, the use of a decision-supporting system practically and in a complex way in the future planning of settlements.

The objective of our studies is to show through the domestic example and with the help of methodological footings already known and used, how to use a decisionsupporting system usefully and in a complex way in the future planning of settlements.

\section{Methods used for building a regional scorecard}

The emphasis is on the method developed; therefore, we discuss this in more detail. To illustrate the workings of our model, we developed the following research.

To achieve the objectives, we used, remodeled, and linked several commonly used, well-established tools in a stricter framework: PESTEL analysis (it is a tool by companies to track the environment they're operating in. PESTEL is an acronym: $\mathrm{P}$ means political, $\mathrm{E}$ means economic, $\mathrm{S}$ means social, $\mathrm{T}$ means technological, E means environmental and L means legal aspect.), Balanced Scorecard (BSC), indicator creation, benchmarking, multi-variant analyses, etc.. However, it was necessary to develop customised analytical and decision supporting methods, partly to connect the elements quantitatively, partly to acquire supplementary information, and

Regional Statistics, Vol. 8. No. 2. 2018: 69-91; DOI: 10.15196/RS080207 
partly to create the tight logical connection between the different work stages (governmental set of instruments, tools-effect matrix, resource matrix, effectiveness matrix, screening prioritisation tools, etc.).

Our starting point is that local governments are active participants in regional processes. We developed a complex method consisting of three matrices to assist government decisions (the regional scorecard matrix (RSC), tools effect matrix (TEM), and resource matrix ( $\mathrm{R} M)$ ).

We describe the method below. Except for the region of Central Hungary, we worked with one district in every region, and included data on every settlement in that district. The selection of a district was based on its diverse regional conditions, but the differences were not excessive. The following six districts were examined: Kapuvár (Győr-Moson-Sopron county, Western Transdanubia region), Tapolca (Veszprém county, Central Transdanubia region), Makó (Csongrád county, South Great Plains region), Nyíradony (Hajdú-Bihar county, North Great Plains region), Szikszó (Borsod-Abaúj-Zemplén county, North Hungary), Tab (Somogy county, South Transdanubia). Data were collected from 126 settlements in six districts (Figure 1) and 24 indicators were developed, based on 50 variables. Each indicator is formed from two to five variables (see Table 1). The data were obtained from the following: TeIR, www.valasztas.hu, www.munka.hu, local data services, Hungarian Central Statistical Office, and www.palyazat.gov.hu. Our study is based on 69 case studies on the most successful economic development practices.

\section{The six districts in Hungary used in the study}

Figure 1

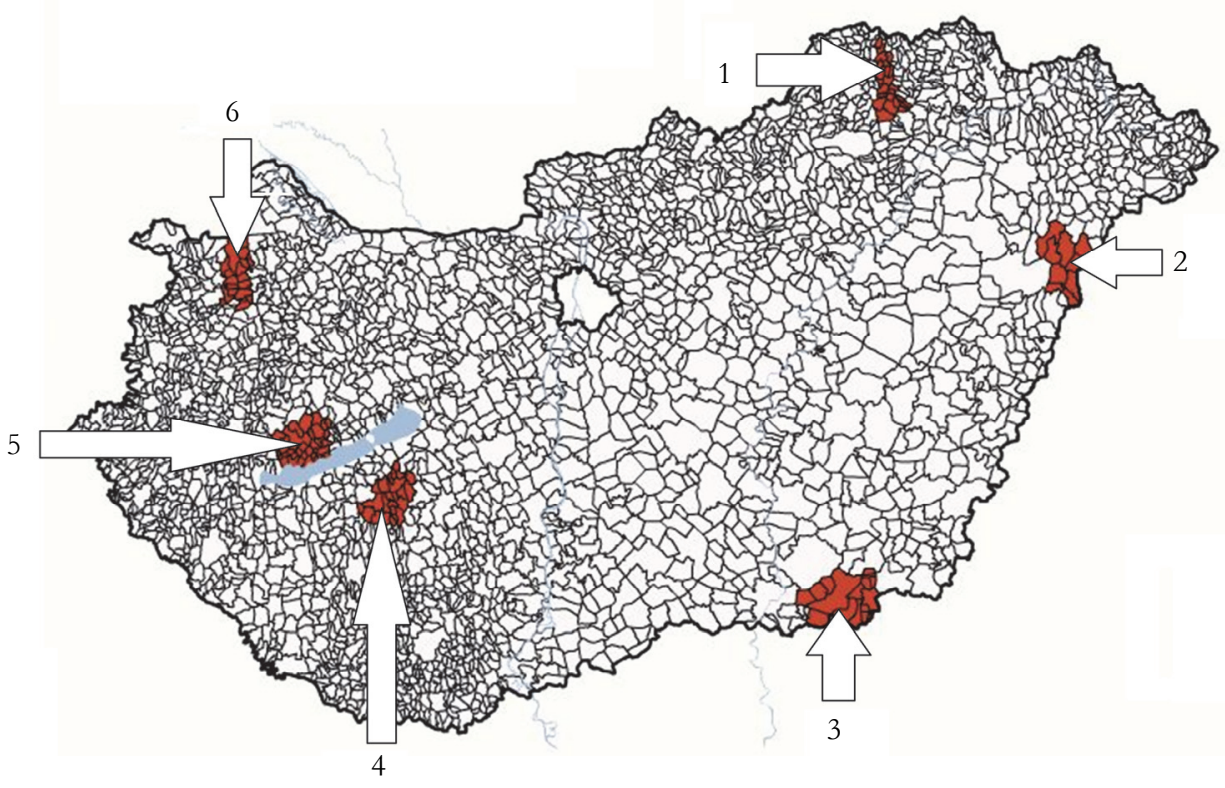

Note: 1. Szikszó, 2. Nyíradony, 3. Makó, 4. Tab 5. Tapolca, 6. Kapuvár.

Regional Statistics, Vol. 8. No. 2. 2018: 69-91; DOI: 10.15196/RS080207 


\section{RSC as a new method in the strategic planning of local econom- ic development}

To identify effective tools, settlements need to determine their action space and opportunities. We used the PESTEL analysis for assessing external factors, and the BSC for assessing the internal factors to create the RSC matrix.

\section{PESTEL: Analysis of external factors}

PESTEL analysis assesses the external environment of an enterprise under the following categories: $\mathrm{P}$ (olitical), $\mathrm{E}$ (conomic), $\mathrm{S}$ (ocial), $\mathrm{T}$ (echnological), $\mathrm{E}$ (nvironmental), and $\mathrm{L}$ (egal). This model is flexible; there are several variations depending on the importance of factors as considered by researchers and enterprises. The analysis of settlements is special because while the decision of a company's management (usually) influences the position of the enterprise, a local government's decision not only influences the organisation, but also the quality of life of the whole community. This makes the influence of the local governments on the development of their economy relevant, by improving the quality of life of the locals.

When adapting the model to local governments, we analysed each of the six factors and determined their ability to describe the surroundings in which the local governments make their strategic decisions. The political, economic, social, environmental, and legal factors are as fundamental for a settlement as they are for an enterprise, even if these impacts apply differently. However, when considering technological changes, the differences are apparent; while in the case of an enterprise the available technology is important, in the life of a settlement the infrastructural background is much more determining, since it also covers technological features, hence, this expanded definition was used.

\section{BSC: Analysis of internal factors}

The BSC, a strategic framework similar to PESTEL, designed for the business world, is flexible and simple in usage (Kaplan-Norton 1996). It examines four business aspects: financial, customer viewpoint, operational processes, and learning development. Based on these aspects, the strategic goals, the indicators which make them achievable, and the actions necessary for these goals are determined. The tool is thus particularly suitable to measure the achievability and effectiveness of the strategic goals, besides determining these goals. Since the strategic goal of a settlement is to develop its economy, the four aspects were subordinated in our method. Readjusting the four aspects of the model implies the following:

- The financial aspect was extended to financial-economic aspect, as it analyses the financial and economic situations of the settlement.

- The customer viewpoint is similar for enterprises and settlements because the service provider and the service user can be identified; however, it is im-

Regional Statistics, Vol. 8. No. 2. 2018: 69-91; DOI: 10.15196/RS080207 
portant not only to measure the effectiveness of the local government as a service provider, but also the opinion of the residents about the settlement, so the quality of life definition is more appropriate.

- The interpretation of operational processes varies significantly for enterprises and local governments; an enterprise is much more flexible about its internal processes, while the internal functioning of local governments is determined by various laws, which allow low flexibility. Nevertheless, local governments can make their operations more effective under the legislative framework and distribute the resources available for development more effectively. This factor was termed organisational efficiency.

- Learning development is more closely connected to an organisation than a settlement, and is defined less from the aspect of learning, so this category was extended. This factor was termed innovational capability.

\section{The synthesis of the external and internal factors: the RSC Matrix}

The RSC matrix is used to aggregate the external PESTEL factors and the internal BSC aspects of a settlement in one table (see Table 1). The rows show the aspects of the Balanced Scorecard, while the columns represent the six factors of PESTEL. The cells of the table show indicators, which characterise the local economy based on specific aspects.

Table 1

The logical frame of the RSC matrix (analysing table) and indicator codes

\begin{tabular}{l|c|c|c|c|c|c}
\hline \multicolumn{1}{c|}{ Factors } & Political & Economic & Social & $\begin{array}{c}\text { Infra- } \\
\text { structural }\end{array}$ & $\begin{array}{c}\text { Environ- } \\
\text { mental }\end{array}$ & Legal \\
\hline Quality of life & IQP & IQE & IQS & IQI & IQEN & IQL \\
Operational efficiency & IEP & IEE & IES & IEI & IEEN & IEL \\
Economy and finance & IFP & IFE & IFS & IFI & IFEN & IFL \\
Innovation & IINP & IINE & IINS & IINI & INEN & IINL
\end{tabular}

The practical use of the RSC matrix depends on the information provided by the variables that are assigned from the official database to the 24 indicators. The indicators in the table can be formed from primary and secondary data sources.

\section{Application of the RSC matrix}

The benchmark data provide several analytical assessments. We compare settlements at the regional and national level, and analyse a settlement's economic character based on size. Below we present the line of research that uses indicators dependent on region or settlement size. For example, we provide an assessment of a settlement's infrastructural environment and internal conditions based on a regional comparison, and also by settlement size (see Tables 2 and 3).

Regional Statistics, Vol. 8. No. 2. 2018: 69-91; DOI: 10.15196/RS080207 
Table 2

Regional comparison of the infrastructural environment and internal conditions of settlements (value/valid element number)

\begin{tabular}{c|r|r|r|r|r|r|r}
\hline Indicator & $\begin{array}{c}\text { Makó } \\
\text { (South } \\
\text { Great Plain) }\end{array}$ & $\begin{array}{c}\text { Nyír- } \\
\text { adony } \\
\text { (North } \\
\text { Great Plain) }\end{array}$ & $\begin{array}{c}\text { Szikszó } \\
\text { (North } \\
\text { Hungary) }\end{array}$ & $\begin{array}{c}\text { Tab } \\
\text { (South } \\
\text { Trans- } \\
\text { danubia) }\end{array}$ & $\begin{array}{c}\text { Tapolca } \\
\text { (Central } \\
\text { Trans- } \\
\text { danubia) }\end{array}$ & $\begin{array}{c}\text { Kapuvár } \\
\text { (Western } \\
\text { Trans- } \\
\text { danubia) }\end{array}$ & Summary \\
\hline IQI & 17.79 & 10.00 & 18.50 & 14.50 & 18.10 & 24.35 & 17.80 \\
IEI & 14.00 & 8.00 & 2.00 & 24.00 & 30.00 & 20.00 & 98.00 \\
IFI & 11.00 & 0.00 & 2.00 & 17.00 & 26.00 & 20.00 & 7.99 \\
IINI & 5.82 & 5.00 & 5.02 & 3.65 & 4.34 & 4.75 & 4.03 \\
& 15.00 & 9.00 & 24.00 & 24.00 & 30.00 & 20.00 & 122.00 \\
& 15.00 & 2.56 & 7.43 & 1.32 & 4.01 & 10.18 & 5.54 \\
& & 2.00 & 24.00 & 24.00 & 33.00 & 20.00 & 125.00
\end{tabular}

Table 3

Comparison of the infrastructural environment and internal conditions of settlements based on settlement size (value/valid element number)

\begin{tabular}{c|r|r|r|r|r}
\hline Indicator & At most 500 & $501-1,000$ & $1,001-5,000$ & Above 5,000 & Summary \\
\hline \multirow{2}{*}{ IQI } & 16.28 & 21.19 & 17.68 & 19.83 & $\mathbf{1 7 . 8 9}$ \\
& 47.00 & 21.00 & 25.00 & 6.00 & $\mathbf{9 9 . 0 0}$ \\
\multirow{2}{*}{ IEI } & 4.93 & 4.57 & 5.44 & 6.04 & $\mathbf{5 . 0 2}$ \\
& 36.00 & 19.00 & 18.00 & 4.00 & $\mathbf{7 7 . 0 0}$ \\
IFI & 3.12 & 4.93 & 6.83 & 8.59 & $\mathbf{4 . 6 6}$ \\
& 62.00 & 25.00 & 30.00 & 6.00 & $\mathbf{1 2 3 . 0 0}$ \\
IINI & 1.53 & 5.16 & 11.23 & 26.95 & $\mathbf{5 . 8 5}$ \\
& 64.00 & 25.00 & 31.00 & 6.00 & $\mathbf{1 2 6 . 0 0}$
\end{tabular}

For public services available in 30 minutes (IQI indicator), the index value is highest for the district of Kapuvár, and least for the district of Nyíradony (see Table 2). This overlaps with the development status of the regions.

If we examine the same indicator based on settlement size (see Table 3), the difference between the smallest (at most 500 people) and the biggest settlements is around $20 \%$. Nevertheless, the concept of a district service organisation is strengthened by the fact that, on average, more than 16 of the basic services can be accessed in 30 minutes by public transport.

Regional Statistics, Vol. 8. No. 2. 2018: 69-91; DOI: 10.15196/RS080207 
The IEI indicator examines the technological state of a local government by measuring the average age of its IT tools; hence, it indirectly assesses the conditions of work efficiency. The variables for the indicator are sourced from local data (see Table 4). Data show that the age of IT tools is high; the collective average is 4.99 years. An average age difference of more than one year is found for the districts of Transdanubia. Based on settlement size (see Table 5), it is surprising that the average age of IT tools in bigger settlements (more than 5,000 people) is 33\% higher than that in settlements with 501-1,000 people.

The IFI indicator refers to a settlement's capability of attracting economic activity. It consists of two factors: the number of middle and large companies per 100 inhabitants, and the index based on infrastructural state. The former measures a settlement's ability to attract investors through existing enterprises, while the latter does the same through accessibility of infrastructure. Based on this indicator, the district of Makó has good conditions, whereas the districts of Tab and Tapolca have poor conditions; the remaining districts show average values (see Table 2). Significant deviation was found among settlements in a district based on settlement size (see Table 3). The value of the indicator for the smallest settlement size is 3.12, whereas for the largest, it is 8.59 . Hence, larger settlements are significantly more attractive to new enterprises.

The infrastructural environment for economic innovation is assessed through the number of broadband connections per 1,000 inhabitants (IINI indicator). The collective average is 5.54, which deviates positively, as expected, for the district of Kapuvár (10.18), and negatively for the districts of Tab (1.32) and Nyíradony (2.56). On comparing the IINI indicator with the IEI value of the same location, we conclude that the low number of broadband connections is an obstacle to regional development. When we examine the values in Table 3, the indicator increases with settlement size.

In summary, the values of two (IFI, IINI) out of four indicators increased with settlement size; the IEI indicator showed some correlation with the settlement size but it mostly showed regional dependence along the southeast-northwest gradient, along with the IQI indicator.

We assess the connection between quality of life and conditions of economic environment to find indicators that are dependent on region or settlement size. Net annual income per inhabitant (thousand Fts), used to define the relation between quality of life and the economic environment (IQE), shows a prominent regional dependency (see Table 4). 
A geographical breakdown of the RSC economic indicators

Table 4 (value/valid element number)

\begin{tabular}{c|r|r|r|r|r|r|r}
\hline Indicator & $\begin{array}{c}\text { Makó } \\
\text { (South } \\
\text { Great Plain) }\end{array}$ & $\begin{array}{c}\text { Nyír- } \\
\text { adony } \\
\text { (North } \\
\text { Great Plain) }\end{array}$ & $\begin{array}{c}\text { Szikszó } \\
\text { (North } \\
\text { Hungary) }\end{array}$ & $\begin{array}{c}\text { Tab } \\
\text { (South } \\
\text { Trans- } \\
\text { danubia) }\end{array}$ & $\begin{array}{c}\text { Tapolca } \\
\text { (Central } \\
\text { Trans- } \\
\text { danubia) }\end{array}$ & $\begin{array}{c}\text { Kapuvár } \\
\text { (Western } \\
\text { Trans- } \\
\text { danubia) }\end{array}$ & Summary \\
\hline IQE & 472 & 406 & 381 & 473 & 550 & 622 & $\mathbf{4 9 5}$ \\
IEE & 15 & 9 & 24 & 24 & 33 & 20 & $\mathbf{1 2 5}$ \\
IFE & 1,527 & -126 & 301 & 2,063 & 1,031 & 2,777 & $\mathbf{1 , 6 7 5}$ \\
IINE & 14 & 4 & 2 & 24 & 30 & 20 & $\mathbf{9 4}$ \\
& 1,326 & 1,205 & 2,044 & 1,947 & 2,857 & 3,660 & $\mathbf{2 , 3 7 2}$ \\
15 & 9 & 16 & 19 & 31 & 19 & $\mathbf{1 0 9}$ \\
& 4.66 & 5.87 & 2.60 & 12.07 & 1.47 & 2.41 & $\mathbf{4 . 6 5}$ \\
& 15 & 9 & 24 & 24 & 30 & 20 & $\mathbf{1 2 2}$
\end{tabular}

The values recorded for the district of Tab, which are the lowest in Transdanubia, coincide with the highest values recorded in the eastern districts of the country. It is worth noting that while the value of IQE decreases in the western parts in a north-south direction, the opposite is observed in the regions east of the Danube.

Table 5

The change in RSC economic indicators with settlement size (value/valid element number)

\begin{tabular}{c|r|r|r|r|r}
\hline Indicator & At most 500 & $501-1,000$ & $1,001-5,000$ & Above 5,000 & Summary \\
\hline \multirow{2}{*}{ IQI } & 464 & 527 & 519 & 584 & $\mathbf{4 9 6}$ \\
& 64 & 25 & 31 & 6 & $\mathbf{1 2 6}$ \\
IEI & 1,585 & 1,938 & 1,593 & 1,453 & $\mathbf{1 , 6 5 8}$ \\
& 47 & 21 & 22 & 5 & $\mathbf{9 5}$ \\
IFI & 2,472 & 2,547 & 1,794 & 3,552 & $\mathbf{2 , 3 5 5}$ \\
& 50 & 23 & 31 & 6 & $\mathbf{1 1 0}$ \\
IINI & 6.82 & 1.69 & 3.00 & 2.58 & $\mathbf{4 . 6 4}$ \\
& 62 & 25 & 30 & 6 & $\mathbf{1 2 3}$
\end{tabular}

The district of Kapuvar, with the highest value, positively deviated from the average, whereas the district of Szikszó displayed the highest deviation in a negative direction (see Table 5). The IQE indicator shows dependency on settlement size; a bigger value is seen in bigger settlements. Although marginally, this indicator gives

Regional Statistics, Vol. 8. No. 2. 2018: 69-91; DOI: 10.15196/RS080207 
better results in settlements with 501-1,000 people, and a weaker result for settlements with 1,001-5,000 people.

We face a similar phenomenon in the analysis of the IEE and IFE indicators. The IEE indicator refers to the efficiency and power of the local economy correlated to the economic environment. The indicator shows the change in local taxing power compared to the increase in GDP (\%). The difference between the western and eastern parts is more obvious for this indicator than for the IQE indicator analysed above. Only the mean value for the district of Makó is comparable with that of the districts of Transdanubia. The district of Kapuvár, with the best result, shows a ninefold value compared to that of the district of Szikszó. The IEE indicator shows a decrease in taxing power in the district of Nyíradony, which is a serious warning sign about the status of the local economy. The north-south gradient experienced with the IQE indicator can be stated only with strong criticism for the IEE indicator, and it is not true for every relation: the correlation is true both for the eastern and western parts, but only for two thirds of the relations.

The indicators do not seem to depend on settlement size when the population is below 500 or above 1,001. The averages show a less than $10 \%$ deviation from each other in these three categories. It is thought-provoking that similar to the IQE benchmark results, the benchmark for settlements with 501-1,001 people is exceptionally high, showing a value more than $16 \%$ than the overall average.

The IFE indicator (gross value added per business) provides feedback about the efficiency of the local economy in the specific macroeconomic environment. It can be clearly concluded that similarly to the IQE indicator, the indicator for Transdanubia shows a significantly higher value than in the districts east of the Danube; a north-south decrease can be observed as well, even more firmly than in the case of IQE benchmarks (see Table 4). This complies with the experience model about the economic power of districts. A north-south decrease can be observed in the eastern parts too, although it is covered by the upward distorting effect of Makó. The average value of the IFE indicator increases with settlement size, whereas the tendency, in accordance with the IQE findings, breaks at settlement sizes of 1,001-5,000 people.

The fourth indicator, IINE, shows the innovation potential. The indicator measures the change in the number of registered enterprises per 1,000 inhabitants (units/1,000 people). Our assumption is that entrepreneurship reflects the innovative ability of the population. Significant differences can be found in the values of the indicator both according to settlement size and districts. Neither a region- nor a settlement size-dependent trend was identified.

The assessed indicators provide valuable information about the settlements and their adaptation to the macroeconomic environment. All benchmark values depend on the geographical location, but a trend between the development of the easternwestern part or the north-south gradient could only be found for the IQE, IEE,

Regional Statistics, Vol. 8. No. 2. 2018: 69-91; DOI: 10.15196/RS080207 
and IFE indicators, and the IQE, IFE indicators, respectively. These indicators are also dependent on the settlement size. Furthermore, for the five indicators mentioned above (IQE-IEE-IFE, IQE-IFE), settlements between 501 and 1,000 people performed better than the expected value, whereas the settlements with 1,001-5,000 people performed lower than the expected value. We could not identify a geographical or settlement size dependency for the IINE indicator.

\section{TEM as a new method in the strategic planning of local economic development}

The TEM is closely related to the RSC matrix introduced earlier, both in structure and functionality, and to the benchmark database built on the RSC matrix. However, its purpose is not only to explore the external or internal circumstances of settlements as in the case of RSC, but also to provide possible solutions to overcome difficulties encountered in the analysis of the situation.

Like the RSC matrix, the TEM examines external factors based on the PESTEL analysis. The components of the RSC matrix and the TEM are the same (political, economic, social, infrastructural, environmental, and legal factors). External factors represent the target areas that can be influenced by the local government's tool set. The tool sets of local governments can influence development beyond laws. This method integrates the following six tools:

- Political: This includes the lobby and relationship building activities and strategy creation of local governments.

- Communicator: The local government has communication responsibilities toward the population and the narrower or wider environment of the settlement, including marketing of the settlement to the outside world (separated from the representation of interest, which belongs to the political tool set) and influencing the settlement attitude.

- Norm setter: Various laws authorise and oblige local governments to create local regulations and decrees, through which they can influence the life of settlements.

- Authoritative: Local governments act in specific cases and usually indirectly as the local authority, and they implement the interests of the local community and check compliance with rules.

- Owner: The local government, depending on the available finances, can exercise their owner rights and continue asset management (e.g. utilisation, estrangement, etc.).

- Occupational: The local government is a significant employer. Therefore, it has influence through increasing (or reducing) the number of available jobs in the settlement.

Regional Statistics, Vol. 8. No. 2. 2018: 69-91; DOI: 10.15196/RS080207 
The tools, as internal factors, provide the columns of the matrix, whereas the external factors of PESTEL provide the rows of the matrix. This presumes that local governments use such tools for their actions and decision making, which affect the external factors related to the settlement. A ' 0 ' signifies no correlation, ' 1 ' signifies correlation, and ' 2 ' shows that a tool has more effects.

This matrix is built by collecting information at the specific spot using the 'soft' method. In the practice of the TEM, the data were based on case studies. Data from each identified best practice on economic development are recorded in a unified Excel sheet; this includes data on the settlements (name, county, region), the literary source, title, short description of the best practice, and the TEM set-up for the specific case, which specifies the municipality roles and the economic factor interaction for which they are used. If a tool had an effect in more areas, we marked the relation in every affected field, whereas if one specific tool had an effect on the same economic factor in a number of ways, we included the number of identified actions in the related field. The values of identical fields in each datasheet are added together in a summary table. This table gives the TEM, which displays the strengths of interactions between the local government tools and the specific economic factors.

A two-step method is used to process the matrices which quantify the information from the case studies. First, the database, which serves as the basis of the analysis, is completed by recreating the matrices. The case studies are displayed in the rows of the database with line numbers, while the columns provide the 36 indicators.

In the second step, the values of the database are summed. Summing the values of the columns by each tool helps measure the strength of the correlation between the tools and their impacts (e.g. the relation between the political tool and the economic environment), and the relative values of the indicators (e.g. what factor was influenced the most by the political tool). The former can help filter the stronger and weaker relations, and the latter can be used to rank the tools based on their effectiveness. Besides this, the effectiveness of indicators within the whole tool spectrum can be measured.

\section{TEM in practice}

To analyse the TEM, we examined publicly accessible case studies. A minimum requirement for a case study to be included in our analysis was that it described at least one economic development measure that enabled the identification of the mean(s) applied and their effects. Thus, when creating the matrix, first, the case studies are examined for the tools used by the local governments; then, the external factors influenced by tools are determined. Below we present the process of gathering data through an example.

Regional Statistics, Vol. 8. No. 2. 2018: 69-91; DOI: 10.15196/RS080207 


\section{Project:}

Designing a remote heating system depending on geothermic power

County:

Settlement:

Bóly

Type of project administrator:

Local government

\section{Source:}

https://www.nth.gov.hu/hu/tevekenysegek/gazdasagfejlesztes/helyigazdasagfejlesztes/otletado-megoldasok-es-jo-gyakorlatok/

geotermikus-energiara-alapozott-tavfuto-rendszer-kialakitasa-boly

(Date of download: 07.08.2015.)

\section{Description:}

The goal of the investment is to decrease and finally cease fossil energy use by the local government and other public institutions, satisfy heat demand through renewable and/or geothermic energy, thereby significantly reduce public expenses, improve the status of the environment, and moderate harmful atmospheric emissions.

During the planning and implementation of the project, the local government continuously cooperated with the municipality of Baranya county, and heat sources were established at its institution in Bóly. The local government allowed the public to get to know the system, its advantages, and the experience with it. In cooperating with the local county, the local government used the political tool to influence the external political environment, through which it secured economic, social, and environmental benefits for the settlement. The project aimed to improve the energy efficiency of public institutions (owner role). Intervention improved the financialeconomic situation of the settlement (economic effect), and by developing the public institution infrastructure (infrastructural environment) and reducing emissions, it improved the state of the environment (environmental effect); by raising the standard of public services it raised the commitment of the population to the settlement (social effect).

Additionally, the management consciously used up-to-date communication tools with which it improved the sensitivity of the settlement population toward environmental protection and cost-effective farming (social and environmental effect), and provided an example for the actors of the local economy to implement similar efficiency-enhancing measures (economic effect). The local government was the owner of the project; thus, it became the owner of the investment, and its property was expanded. Table 6 contains this information.

Regional Statistics, Vol. 8. No. 2. 2018: 69-91; DOI: 10.15196/RS080207 
Data on actions similarly analysed are collected in one database. As a result, on one hand, a case collection is created that contains the best practices and could be used as a sample for planning settlement development actions; on the other, the TEM, showing the efficiency of the local government's tools, becomes visible by summarising the numerical results. Every record in the database contains the processed data of specific case studies. Table 7 is the summary of 69 case studies in the districts examined. In Table 7, highlighted fields contain the occurrence of each indicator reflected in every case study. The summary row shows the influence of the local government on external factors, while the summary column provides information on the efficiency of the tools in developing the economy. Table 7 shows a 'heat map' of the TEM. The most prominent interaction areas between the means and the environment can be identified with the heat map (marked with warmer colours). Warmer colours imply higher values, and vice versa. It might be surprising, but the results of the assessment show that the strongest tools are related to political and communication roles.

Table 6

TEM data for the energetics project of Bóly

\begin{tabular}{l|c|c|c|c|c|c}
\hline \multicolumn{1}{c|}{$\begin{array}{c}\text { Area of effect/ } \\
\text { Tools }\end{array}$} & Political & Economic & Social & $\begin{array}{c}\text { Infra- } \\
\text { structural }\end{array}$ & $\begin{array}{c}\text { Environ- } \\
\text { mental }\end{array}$ & Legal \\
\hline $\begin{array}{l}\text { Political } \\
\text { Communicator }\end{array}$ & 1 & 1 & 1 & & 1 & 1 \\
$\begin{array}{l}\text { Norm setter } \\
\text { Authoritative } \\
\text { Owner } \\
\text { Market }\end{array}$ & 1 & 1 & & 1 & \\
\end{tabular}

TEM results depicted on a heatmap

Table 7 (based on the 69 case studies examined)

\begin{tabular}{|l|r|r|r|r|r|r|r|r|}
\hline $\begin{array}{c}\text { Area of effect/ } \\
\text { Tools }\end{array}$ & Political & $\begin{array}{c}\text { Econo- } \\
\text { mic }\end{array}$ & Social & $\begin{array}{c}\text { Infra- } \\
\text { structural }\end{array}$ & $\begin{array}{c}\text { Environ- } \\
\text { mental }\end{array}$ & Legal & $\sum$ (Tools) $)$ & $\begin{array}{c}\text { Applica- } \\
\text { tion rate, } \\
\%\end{array}$ \\
\hline Political & 15 & 40 & 45 & 17 & 12 & 0 & 129 & 30 \\
\hline Communicator & 3 & 46 & 50 & 15 & 18 & 0 & 132 & 30 \\
\hline Norm setter & 0 & 8 & 8 & 6 & 1 & 0 & 23 & 4 \\
\hline Authoritative & 0 & 4 & 4 & 1 & 0 & 1 & 10 & 2 \\
\hline Owner & 0 & 32 & 32 & 19 & 8 & 3 & 94 & 22 \\
\hline Market & 0 & 23 & 24 & 3 & 1 & 0 & 51 & 12 \\
\hline Altogether & 18 & 153 & 163 & 61 & 40 & 4 & 439 & 100 \\
\hline
\end{tabular}


If we examine the areas to be influenced, we find that local governments can influence the economic and social relations to a significantly lesser extent, but the influence is strong in the fields of infrastructure and environment. The other end of the scale is provided by relations with a ' 0 ' value, that is, a correlation could not be created between, for example, the employer function and the legal environment, or between the authoritative tool and the political environment. This does not mean that effective actions cannot be planned with these, but in the case studies, they did not have importance.

\section{RM as a new method in the strategic planning of local economic development}

The RM shows the internal factors affected by government tools. The basis of the RM is provided by the case studies processed in the TEM; internal factors (BSC aspects), which were discussed in the section on the RSC matrix (Analysing table), are assigned to local government tools already identified. By identifying this connection, it can be determined which internal factors are affected by the tools. The relation is indicated in the fields of the matrix by a ' 1 ', or by a ' 2 ' in case of multiple connections (that is, one tool can affect the same internal factor in many ways).

The rows of the RM denote the case studies, whereas the columns contain the indicators that describe the relation between local government tools and internal factors.

The data summary contained in the rows is constructed according to categories (quality of life, organisational effectiveness, and innovation). The summary and ratio measure the frequency of application of local government tools within the specific internal factors. An example is illustrated here: the six local government tools, which influence quality of life, are measured to compare the extent to which they correlate with the internal factors; among 70 case studies, the political tool was used ten times, while the communicator tool was used seven times to impact quality of life; these occurrences can then be compared with the aggregate within the category, as well as the occurrences within the entire internal factors spectrum.

\section{RM in practice}

Below we present the data-processing method used to build the RM through a specific example, the project of Bóly, described earlier.

In this case study, the local government cooperated with the municipality of Baranya county during the planning and implementation of the project, and heat sources were established at the institution in Bóly.

The columns in the RM contain local government tools identified by creating the TEM, and the rows contain the BSC viewpoints modified according to a sector's features. To create the TEM, we identified the usage of political, communicator, and

Regional Statistics, Vol. 8. No. 2. 2018: 69-91; DOI: 10.15196/RS080207 
owner tools in the case study; therefore, in the working phase, internal factors must be identified that are affected by this action.

As a first step, we examine the political tools based on new aspects. In this case study, the use of political tools included external networking activities and cooperation (with the municipality of Baranya). Cooperation is an example of political innovation, which could not have been made possible without involving local financial resources. In this stage of the project, the policy's social capital was measured by the difference between the current and expected quality of life, which leads to the relation between communicator functions and quality of life. Enough means were needed to ensure proper project communication and to build an innovative communication solution based on local conditions. The local government won the support of the locals by communicating and popularising the benefits and novelty of the investment (see Table 8).

Table 8

Enumerator resource matrix (RM) for the energy project of Bóly

\begin{tabular}{l|c|c|c|c|c|c}
\hline $\begin{array}{c}\text { Tools/Internal } \\
\text { factors }\end{array}$ & Political & $\begin{array}{c}\text { Communi- } \\
\text { cator }\end{array}$ & $\begin{array}{c}\text { Norm } \\
\text { setter }\end{array}$ & $\begin{array}{c}\text { Autho- } \\
\text { ritative }\end{array}$ & Owner & Market \\
\hline $\begin{array}{l}\text { Quality of Life } \\
\text { Operational }\end{array}$ & 1 & 1 & & & 1 & \\
$\begin{array}{c}\text { Efficiency } \\
\text { Economy and } \\
\text { Finance }\end{array}$ & 1 & 1 & & & 1 & \\
Innovation & 1 & 1 & & & 1 &
\end{tabular}

It is vital that invested resources are rewarded; the Bóly project received a positive feedback. Innovation potential increased in the settlement, economic-financial resources grew due to savings, and the policy's social credit was strengthened due to improvement in the quality of life as an effect of the project.

Table 11 shows the results based on the 69 case studies in the six districts. By summarising the columns, we get an image of the occurrence of relations, whereas the summary column provides information on the frequency of resource use and the effectiveness of the resources available for the different tools. The summarised data of specific relations from the database (QP, IP, etc.) are provided in the highlighted areas. Instances of local government tools are shown in the summary row, whereas the summary column contains the application rate of specific internal factors.

Table 9 shows a heat map of the TEM. The heat map differentiates the relations between the local government tools and internal factors with a three-colour scale. Bright red denotes a strong relation, and grayscale colours denote weaker relations.

The closest correlation was between the communicator tool and quality of life as an internal factor. This supports the theory by communication professionals that 
perception is as important as objective facts. Medium to strong relations are observed in significant numbers (13-21\%), marked with a light purple. The results show that local governments used the authoritative and norm setter tools in few cases, although these had the lowest resource requirements.

Table 9

TEM results depicted on a heatmap (based on the 69 case studies examined)

\begin{tabular}{|l|r|r|r|r|r|r|r|c|}
\hline $\begin{array}{l}\text { Tools/ } \\
\text { Internal factors }\end{array}$ & Political & $\begin{array}{c}\text { Com- } \\
\text { mu- } \\
\text { nicator }\end{array}$ & $\begin{array}{c}\text { Norm } \\
\text { setter }\end{array}$ & $\begin{array}{c}\text { Authori- } \\
\text { tative }\end{array}$ & Owner & Market & $\begin{array}{c}\text { Inter- } \\
\text { nal } \\
\text { factors }\end{array}$ & $\begin{array}{c}\text { Appli- } \\
\text { cation } \\
\text { rate, \% }\end{array}$ \\
\hline Quality of life & 38 & 45 & 1 & 4 & 21 & 21 & 130 & 38 \\
\hline $\begin{array}{l}\text { Organizational } \\
\text { effectiveness }\end{array}$ & 16 & 8 & 5 & 0 & 13 & 2 & 44 & 13 \\
\hline $\begin{array}{l}\text { Economy- } \\
\text { finance }\end{array}$ & 31 & 34 & 4 & 4 & 32 & 21 & 126 & 37 \\
\hline Innovation & 13 & 21 & 2 & 2 & 5 & 0 & 43 & 13 \\
\hline Altogether & 98 & 108 & 12 & 10 & 71 & 44 & 343 & 100 \\
\hline
\end{tabular}

Among the internal factors, quality of life and economy-finance stand out; this implies that a prerequisite of successful local government actions is securing social support for local quality of life and the required financial resources. However, it is surprising that organisational effectiveness and innovation appear at a low rate.

\section{Analysis of the main components of indicators}

In the earlier sections we showed that some indicators are correlated to settlement size, while others are correlated to regional location; however, some indicators correlate with neither.

In the following paragraphs we analyse the relations between different indicators and identify indicator groups whose elements are not entirely independent of each other. The practical significance of this analysis is that the identified correlations might enable the indirect development of areas which cannot be influenced as much, by using interventions aimed at areas characterised by the related indicators. Six main components were identified by reducing data.

Component $F_{1}$ contains indicators on development management (see Table 10). The IEEN characterises investments on environmental protection; the IFP provides information on a settlement's ability to exercise resources; IEP characterises the operational efficiency of the management through the financial planning accuracy of the local government. An assessment of the dimensions of the component indicators shows that two indexes portray the political environment, and two contain

Regional Statistics, Vol. 8. No. 2. 2018: 69-91; DOI: 10.15196/RS080207 
aspects of organisational effectiveness. The factors are: efficiency of environmental management (IEEN), ability to create resources (IFP), and efficiency of resource utilisation (IEP).

Component $\mathrm{F}_{2}$ includes local livelihood opportunities. According to this, two indicators refer to the quality of life, and three relate to the social environment (see Table 10).

Component $\mathrm{F}_{3}$ contains three infrastructure related indicators (IQI, IEI, IINI); therefore, this component became the factor's dominant feature. It covers a wide spectrum: from the accessibility of public services to the quality of IT tools of the local government, that ensure environmental support of the economy, to the broadband access available in the settlement (see Table 10).

Table 10

Characteristics of the components $F_{1}, F_{2}$, and $F_{3}(N=132)$

\begin{tabular}{|c|c|c|c|}
\hline $\begin{array}{l}\text { Variables in the com- } \\
\text { ponents }\end{array}$ & Communalities & Retained information $(\%)$ & Min./Max. \\
\hline \multicolumn{4}{|c|}{ F1: Development management } \\
\hline IEEN & 0.399 & \multirow{3}{*}{36.983} & -5.21781 \\
\hline IFP & 0.258 & & \\
\hline IEP & 0.453 & & 4.61286 \\
\hline \multicolumn{4}{|c|}{ F2: Livelihood opportunities } \\
\hline IQE & 0.827 & \multirow{4}{*}{62.167} & -2.95699 \\
\hline IQS & 0.681 & & \\
\hline IES & 0.249 & & 1.99226 \\
\hline IFS & 0.730 & & \\
\hline \multicolumn{4}{|l|}{ F3: Infrastructure } \\
\hline IQI & 0.553 & \multirow{3}{*}{47.078} & -2.72704 \\
\hline IEI & 0.444 & & \\
\hline IINI & 0.416 & & 2.74847 \\
\hline
\end{tabular}

Component $\mathrm{F}_{4}$ denotes entrepreneurial activity (see Table 11). The component indicators provide information about the relationship between innovativeness and the economic-financial characteristics. These indicators represent local entrepreneurship: the number of new and middle-sized enterprises, and the value added by enterprises show the functioning of the local business sphere from multiple views. 
Components $F_{4}, F_{5}$, and $F_{6}(N=132)$

Table 11

\begin{tabular}{c|c|c|c}
\hline $\begin{array}{c}\text { Variables in the compo- } \\
\text { nents }\end{array}$ & Communalities & $\begin{array}{c}\text { Retained information } \\
(\%)\end{array}$ & Min./Max. \\
\hline
\end{tabular}

F4: Entrepreneurial activity

\begin{tabular}{l|l|l|l} 
IFE & 0.521 & & -4.48234 \\
IFI & 0.282 & 36.142 & \\
IINE & 0.281 & & 6.24101
\end{tabular}

F5: Settlement management

\begin{tabular}{l|l|l|r} 
IQE & 0.642 & & -1.92999 \\
IQS & 0.386 & 47.041 & \\
IES & 0.383 & & 1.99226
\end{tabular}

F6: Social activity

IQI

IEI

IINI

0.374
0.608
0.251

41.094

$-3.49769$

2.69848

Indicator group, $\mathrm{F}_{5}$, refers to settlement management. The two efficiency and two legal dimensions relate to the security and flexibility of the regulator environment.

Component $\mathrm{F}_{6}$ contains indicators characterising local social activity. Political activity, lobbying power, stability of the local management, and civilian courage are included in this factor.

The question of whether we reached the original goal with the component analysis arises, that is, finding a way to shape areas that are difficult to influence. We thus compare the values of the Effect matrix with the position of the factors (see Table 12).

Table 12

Position of factor-forming indicators in the analysis table

\begin{tabular}{l|c|c|c|c|c|c}
\hline \multicolumn{1}{c|}{$\begin{array}{c}\text { Effects » } \\
\text { Internal factors }\end{array}$} & Political & Economic & Social & $\begin{array}{c}\text { Infra- } \\
\text { structural }\end{array}$ & $\begin{array}{c}\text { Environ- } \\
\text { mental }\end{array}$ & Legal \\
\hline Quality of Life & 705 & 4,769 & 5,160 & 1,793 & 1,456 & 67 \\
Operational Efficiency & 264 & 1,510 & 1,624 & 675 & 447 & 39 \\
Economy and Finance & 567 & 4,359 & 4,671 & 1,736 & 1,265 & 100 \\
Innovation & 258 & 1,670 & 1,819 & 645 & 576 & 17
\end{tabular}

Three factors are included in component $\mathrm{F}_{1}$ : one is difficult to influence, while the other two can be influenced somewhat easily; here we can hope for a real added option only by the synergy of factor-forming indicators. In groups $\mathrm{F}_{2}$ and $\mathrm{F}_{4}$, the situation is the opposite: local governments have good tools for developing almost

Regional Statistics, Vol. 8. No. 2. 2018: 69-91; DOI: 10.15196/RS080207 
all relations. Therefore, the factor effect is not relevant, although because of a contrary reason. The situation is different for components $F_{3}, F_{5}$, and $F_{6}$. In these groups, both areas that cannot be developed easily are connected to one that can be influenced somewhat easily, which, if needed, can enable the indirect development of the two weaker relations.

To summarise, the main component analysis provides adequate tools for indirectly developing six areas that can be influenced only slightly. We could not find direct development tools for three factor-forming areas, while another three areas can be influenced only slightly and they are not a part of the main component analysis.

\section{Forming settlement clusters based on main components}

In the following paragraphs we examine the creation of settlement clusters based on the main components built from the indicators of the 132 settlements examined (see Table 13).

We identified four clusters in our analysis. Settlements in category 1 have good infrastructural characteristics. Settlement development takes place with serious fundraising, which is based on prominent management. Quality of life is better than the average; however, entrepreneurship is average. Social activity is strikingly modest, as if the locals would turn their awakening initiative for the time being toward economic activities. We named this cluster 'Emerging', based on the good/improving conditions and strong control. $8 \%(\mathrm{~N}=11)$ of the assessed settlements belonged to this group. The cities of Tapolca, Balatonfüzfó, Makó, Csongrád, Szikszó, and some smaller settlements such as Alsóvadász and Halmaj, belong to this group.

Table 13

Forming settlement clusters based on main components

\begin{tabular}{l|c|c|c|c}
\hline \multirow{2}{*}{} & \multicolumn{4}{|c}{ Cluster } \\
\cline { 2 - 5 } & $\begin{array}{c}\text { Emerging } \\
\mathrm{N}=11\end{array}$ & $\begin{array}{c}\text { Endangered } \\
\mathrm{N}=10\end{array}$ & $\begin{array}{c}\text { Opportunist } \\
\mathrm{N}=101\end{array}$ & $\begin{array}{c}\text { Fortunates } \\
\mathrm{N}=10\end{array}$ \\
\hline $\begin{array}{l}\text { Development- } \\
\text { management }\end{array}$ & 0.78156 & -1.95610 & 0.11981 & -0.11370 \\
$\begin{array}{l}\text { Livelihood } \\
\text { opportunities }\end{array}$ & 0.21461 & 0.21539 & -0.13685 & 0.93077 \\
$\begin{array}{l}\text { Infrastructure } \\
\begin{array}{l}\text { Entrepreneurial activity } \\
\text { Settlement } \\
\text { management }\end{array}\end{array}$ & 0.02899 & -0.23201 & -0.17123 & 0.20891 \\
Social activity & 0.97450 & 0.35374 & -0.20314 & 2.29383 \\
& -1.58204 & 0.43286 & -0.14447 & 0.03337 \\
& & & 0.09033 & 0.39501
\end{tabular}

The second cluster is similar in size but has a significantly different character. The livelihood characteristics, similarly to the first cluster, are favourable, with a 
weaker but still an imaginative management. However, management efficiency is much weaker and perhaps partly as a result of this, underdevelopment is grave due to the infrastructural conditions. It is interesting that social activity is the biggest here, while entrepreneurship is the weakest among all clusters. We found the ' $E n$ dangered attribute the most fitting for this cluster (e.g. Nyírábrány, Hövej, and Kövegy).

Most of the settlements $(\mathrm{N}=101,76 \%)$ belong to the third cluster. Modest development and livelihood opportunities below the total settlement average characterise this group. Underdeveloped infrastructure, insignificant entrepreneurship, and average social activity are the norm. Settlement management is the weakest for this group. Stagnation or slow deterioration characterises these settlements. This cluster was titled 'Opportunists'.

The fourth cluster is a not too large group $(\mathrm{N}=10,8 \%)$ of settlements enjoying prosperity. The outstanding livelihood is based on a strong and broadening entrepreneur stratum and the best infrastructural conditions among all clusters. Relative welfare allows a more spirited social life; however, management and development works are neglected to some extent. It is interesting that we find smaller settlements in this cluster, which explains the few but successful enterprises, but when taking the settlement size into consideration, a significant workplace number, just like it explains the modest ratio of liable sources, because the current rural development policy does not favour smaller settlements. The cluster received the name 'fortunates' (representatives of this cluster are Kékkút, Kapoly, Kára (sic.), and Veszkény).

\section{Conclusions}

We described a method (RSC matrix) that combines the PESTEL and the BSC systems, that not only displays the external environmental factors and the internal resources at the same time, but also illustrates the network between them. We assigned variables to the indicators in the RSC matrix, which we used to study six Hungarian districts. We found that some factors were dependent on settlement size, while others were dependent on location, and some factors did not depend on either. We paid special attention to those indicator groups wherein the change in elements was not independent from each other. We conducted a main component analysis to examine the possibility of indirectly developing factors that can be influenced with difficulty. We found adequate tools with the main component analysis for indirectly developing six areas that can be influenced only slightly. We could identify four clusters by using the main components created by the indicators of the 132 settlements examined. Settlements in category I, the 'emerging' group, have good infrastructure and development takes place with serious fundraising, which is based on prominent settlement management. Only a few settlements belong here $(\mathrm{N}=8)$. The second cluster, 'endangered', is characterised by low management performance, and weak entrepreneurial activity, but strong social activity. Majority of

Regional Statistics, Vol. 8. No. 2. 2018: 69-91; DOI: 10.15196/RS080207 
the settlements $(\mathrm{N}=101,76 \%)$ belong to cluster 3, the 'opportunists'. This cluster is characterised by underdeveloped infrastructure and insignificant entrepreneurship; average social activity can be observed from the numbers. The fourth cluster, the 'fortunate' category, is characterised by a broadening entrepreneurial layer and excellent infrastructural conditions with strong civilian activity, although with a less active management. There are ten settlements in this cluster.

Our novel results are methodological adaptations and analytical and evaluation techniques for optimising decision-making objectives. Our new adaptation is the indicator matrix (RSC matrix). The model shows the relation between external factors affecting settlements and internal factors characterising the settlement with quantitative tools. The logical system of the reference database needed for additional analyses is novel since it enabled comparative work based on many aspects. From a comparative analysis of benchmark tables, we deduced that some of the indicators are dependent on region and/or settlement size. We identified six characteristic municipal roles based on regulation features of the municipal sphere; to each role we matched the set of instruments that can be attached by the legislator, which enabled the assessment of the relation between the set of instruments and the environmental factors, as well as the resources of the settlement. We summarised the relations in the TEM and the RM. The two matrices can support the planning of economic development actions. The effect matrix is used in a novel way regarding its methodology; it helps in revealing the influencability of economic areas characterised by different indicators. The matrix created and the heat map built on the values of the specific fields gives a plastic image about the extent of the direct influencability by local governments.

\section{REFERENCES}

BODOR, Á.-GRÜNHUT, Z.-HORECZKI, R. (2017): Városi bizalmatlanság, vidéki bizalom. Esetleg fordítva? A bizalom és a településtípus összefüggései Európában/ Urban Distrust, Rural Trust. Or Vica Versa? Linkage Between Trust and Types of Settlements in Europe/ Területi Statisztika, 2017, 57 (4) 406-421. https://doi.org/10.15196/TS570404

BARTIK, T. J. (1995): Economic Development Strategies. Upjobn Institute Working Paper No. 95-33. http://research.upjohn.org/up_workingpapers/33

ČApKovÁ, S. (2005): Local Government and Economic Development. — Čapková, S. (ed.) Local Government and Economic Development (pp. 1-19). Budapest: Open Society Institute.

FARAGÓ, L. (2004): A közösségi (területi) tervezés szerepe a gazdaságfejlesztésben. (The role of community (regional) planning in economic development) In: PÁLNÉ KOVÁCS I. (Ed.): Versenykeépesség és igazgatás (Competitiveness and management) pp. 57-66. Pécs

G. FEKETE, É. (2005): Vidékpolitika (1.) (Rural Policy 1.) Institute of World and Regional Economics, Miskolc University, Miskolc

JedynaK, W.-NAgy, H.-ArdeleAn, L. (2015): Local development in the Central- European perspective. Rzeszów: University of Rzeszów.

Regional Statistics, Vol. 8. No. 2. 2018: 69-91; DOI: 10.15196/RS080207 
Kaplan, S. R.-NorTOn, P. D. (1996): The Balanced Scorecard: Translating Strategy into Action. Harvard Business School Press.

KŐsZEGI, M.-BOTTLIK, Zs.-TelBiSZ, T.-MARI, L. (2015): Human-environment relationships in modern and postmodern geography Hungarian Geographical Bulletin 64 (2015) (2) 87-99.

LENGYEL, I. (2003): Verseny és területi fejlődés: térségek versenyképessége Magyarországon (Competition and territorial development: the competitiveness of regions in Hungary). JATEPress. Szeged

LuDESCHER, G. (2010): A vállalkozások és a közösségek szerepe a rurális térségek megújulásában. (Function of the enterprises and communities in connection with regeneration of the rural areas.) Pécs: ID Research Kft./Publikon Kiadó.

MEZEI, C. (2006): A helyi gazdaságfejlesztés fogalmi meghatározása. (The concept of local economy development.) Tér és Társadalom 20 (4), 85-96.

Nagyné Molnár, M.-Lendvay, E. (2016): Possibilities to identificate action points in economic development of local management. VADYBA Journal of Management 1 (28), 111-117.

PÁGER, B.-ZSIBÓK, Zs. (2014): The measurement of territorial differences in the information infrastructure in Hungary and the South Transdanubian Region Regional Statistics 2014, vol.4, No 2: 55-70. https://doi.org/10.15196/RS04204

PÉTERI, G. (1994): A vállalkozó önkormányzattól a helyi gazdaságfejlesztésig (From entrepreneurship to local economic development) Comitatus. 1994/(1.) pp. 14-20.

\section{Data base and case studies references}

http://kozfoglalkoztatas.kormany.hu/jo-gyakorlatok

http://www.ksh.hu/apps/hntr.telepules?p_lang=HU\&p_id $=08590$

https://www.nth.gov.hu/hu/tevekenysegek/gazdasagfejlesztes/helyi-gazdasagfejlesztes/ otletado-megoldasok-es-jo-gyakorlatok

http:/ /www.legjobbonkormanyzatigyakorlatok.hu

www.palyazat.gov.hu

www.valasztas.hu

www.munka.hu 